\title{
Keep Diversity-Make Standards! Spaces of Standardization for Diversity Analyzed through Cattle Breeding Industry
}

\author{
LIDIA CHAVINSKAIA \\ INSTITUT NATIONAL DE RECHERCHE POUR L'AGRICULTURE, L'ALIMENTATION ET \\ L'ENVIRONNEMENT \\ LABORATOIRE INTERDISCIPLINAIRE SCIENCES INNOVATIONS ET SOCIETE \\ UNIVERSITE GUSTAVE EIFFEL \\ ALlison MARIE LOCONTO \\ INSTITUT NATIONAL DE RECHERCHE POUR L'AGRICULTURE, L'ALIMENTATION ET \\ L'ENVIRONNEMENT \\ LABORATOIRE INTERDISCIPLINAIRE SCIENCES INNOVATIONS ET SOCIETE \\ UNIVERSITÉ GUSTAVE EIFFEL
}

\begin{abstract}
Standardization as spaces of diversity was introduced by Loconto and Demortain (2017) to advance the sociology of standards. Their analytical framework for studying standardization processes in interactive spaces is mobilized and expanded upon in this article in order to address the problematic relationship between standards and diversity. Studying industrialized animals highlights the existing tensions between these opposing forces and the socio-technical attempts to reconcile them. Using a socio-historical approach, we analyze cattle breeding standards as they pass through three interactive spaces of standards: "standards in the making," "standards in action," and "standards in circulation." Drawing from the notion of ecology, we highlight the need for contextualization in order to better understand processes of standardization in a fourth space of "standards in interaction." The contours of this space are demonstrated through an analysis of the International Bull Evaluation Service (Interbull), which is a space of commensuration for cattle breeding values. Linear interpretations of standardization processes are thus challenged with an empirical demonstration of how standardization can be harnessed to preserve and even enhance diversity.
\end{abstract}

\section{Keywords}

standards; standardization; diversity; commensuration; cattle breeding; genetics

'Lidia Chavinskaia, Email: lidia.chavinskaia@gmail.com

${ }_{2}^{2}$ Allison Marie Loconto, Email: allison-marie.loconto@inrae.fr

Copyright (c) 2020 (Lidia Chavinskaia, Allison Marie Loconto). Licensed under the Creative Commons Attribution Noncommercial No Derivatives (by-nc-nd). Available at estsjournal.org. 


\section{Introduction}

The ubiquity of standards, their diversity, their compatibility, and their socio-political implications represent a major issue for contemporary societies and a growing field of inquiry for science and technology studies (STS). Though extensive research has illustrated a wide variety of approaches, the topic remains of high interest and scholars have called for more systematic research (Timmermans and Epstein 2010; Busch 2011; Loconto and Demortain 2017). Inter alia, the dynamic relationship between standards and standardization (Bowker and Star 2000; Brunsson et al. 2012; Higgins and Larner 2010; Loconto and Demortain 2017; Loconto 2017) is increasingly important as societies move towards globally integrated socio-technical systems that demand both standardization and diversification. Addressing tensions between standards and diversity as part of more generic tensions between the global and the local, the universal and the particular, scholars have historically analyzed sociotechnical pathways between two antagonistic points.

To nuance the linear depictions of standards and standardization, Higgins and Larner (2010) first introduced the notion of "standardizing work as an ongoing and never completed process of 'making up' objects, subjects and practices of modern governing" (p.205). This definition opened up standards and standardizing to the dynamics of simultaneously producing uniformity and diversity as two sides of a locally contingent process. Loconto and Demortain (2017) furthered this proposition by positing standardization as spaces of diversity to explain the different types of local contingencies consistently encountered throughout the life of a standard. They argue that "standardization can [...] be defined as a process of controlling and framing diversity, rather than one of only reducing it" (Loconto and Demortain 2017, 384-385). In this sense, a standard lives in three spaces of standardization where diversity is constantly reemerging: (i) standards in the making, (ii) standards in action and (iii) standards in circulation. These are interactive spaces where ontologies and practices are co-constituted and offer a way of dealing with the problems of duality in socio-technical standardization. However, to date, the empirical demonstration of applying this approach is limited. We propose to advance this body of literature by exploring the production of diversity through the standardization of cattle breeding.

First, however, the concept of "space" needs clarification. As proposed by Rip and Joly (2012), "space" is one of numerous attempts to conceptualize "where things happen" - and is found somewhere between fields (Bourdieu and Wacquant 1992; Fligstein and McAdam 2015), worlds (Becker 2011), networks (Callon 1986; Akrich, Callon and Latour 2006; Powell et al. 2005), arenas and forums (Fouilleux 2000; Joly and Marris 2003). The space refers to a social context but with material and geographical features. The latter is more important in Rip and Joly's concept of space than in the above cited notions that tend to neglect the geographic elements. Spaces thus have boundaries, even if porous and more or less diffuse. They are structured in terms of affordances and rules for interactions to preserve social, technical, and geographical boundaries. Thus, standards draw boundaries as they are applied in specific spaces of local action. This notion goes beyond the claim of the importance of "context" as we argue that the ecology that encompasses and determines the modes of making, applying and circulating of technical objects 
(Star and Griesemer 1989) is co-constitutive (Jasanoff 2004) of what can become standardized through the application of standards. This consideration leads us to reflect on the dynamic relationships between standards and their ecologies as they move from one space of action to another. Is the ecology fundamentally part of a technical standard? Does a standard that enters a new space with a different ecology automatically become a new standard? If we answer yes to these questions, the circulation of standards across different ecologies logically creates diversity (as some elements of ecologies are selectively standardized). The question then turns into a techno-political one, which is the purpose of this article: How might we account for this diversity when standards interact across different ecologies?

This article answers this question through the analysis of standards for selective breeding of cattle. Farm animals present a significantly interesting case. Their double ontology enables us to highlight an obvious, but also highly original, tension between industrial standardization and the preservation of biological/genetic diversity that is needed for population survival. Furthermore, the nature of farm animals as living and agential beings fully justifies the call to clarify the entrenched relationships between industrial standards and their ecologies. ${ }^{3}$ In the first part of this article, we explore cattle breeding activity through three spaces: breed creation as a space of "standards in the making"; animal production as a space of "standards in action"; and the genetic resources market as a space of "standards in circulation." The data collected to define these three spaces are based on participant observation among cattle breeding specialists and secondary sources. The second part of this article presents the activity of Interbull (International Bull Evaluation Service) and argues for the inclusion of a new space of "standards in interaction." Data to support this proposal were gathered during one year of qualitative fieldwork that included semi-structured interviews, archival research, and non-participant observations within the international professional network of cattle geneticists. This fourth space is characterized as one of commensuration of national breeding evaluation standards and presents a techno-political account of standards' diversity in ecologies.

\section{The Three Spaces of Standardization to Analyze the Cattle Breeding Industry}

The standardization of industrialized animals and the preservation of their genetic diversity have both been inherent to the animal selection activities developed by humans since the Neolithic era. The tension between these two contradictory processes has increased with the creation of breeds, and has become critical with the industrial intensification of animal breeding and its globalization over the last 50 years. With the pressure of market forces pushing the standardization process to its extreme, how can sufficient genetic variability be preserved to ensure the sustainable genetic breeding of animals? This question has become a real challenge for the animal breeding community, which is seeking a degree of diversity despite the trend towards

"In this article, we use the term "ecology" to refer to what breeders call "environment." We do this as ecology exists as an STS notion within studies on knowledge infrastructures and institutional ecologies. Thus, we use this term to capture both this theoretical meaning and the actors' meaning of "environment" throughout the text. 
global standardization. The following sections trace the life of these standards to demonstrate how diversity continuously re-emerged through the standardization process.

\section{Breed creation as a space of standards in the making}

Genetic breeding, or selection, or improvement, is one of the most evident standard setting processes within the animal industry. Since the creation of stud breeding methodology by Bakewell, an 18 ${ }^{\text {i }}$ century English farmer (Russell 1986; Vissac 2002), the reproduction of animals has endeavored to entrench desirable traits at group level (and no longer at individual level). These groups are called breeds. From then on, an industrial orientation towards animal breeding (i.e. the improvement of breeds through the selection of the best progenitors) with intentional standardization of animals developed. Each breed was created for a specific economic purpose informed by the consumer demand (mainly for milk and meat), farmers' needs (docility, productivity, suitable udder position for milking, etc.), their aesthetical preferences (color and pattern, horn shape, etc.) and a given geo-climatic environment. According to Bakewell's approach, based on the so-called "Bakewell's doctrine" of genealogical breeding (Vissac 2002), desirable traits are defined and fixed through mating between animals that are related. Females are separated from males for better control of the reproductive process. The male becomes the main provider of germplasm and thus the vector of genetic progress. Progress is understood here as the steady increase in animal productivity within the same breed standard. Herd books ensure pedigree traceability, recording all information about mating operations, parents, and newborns. This process and its continuity over time are managed by breeding associations or breeding societies, comprising breeders and farmers, to guarantee breeds' compliance with the standard.

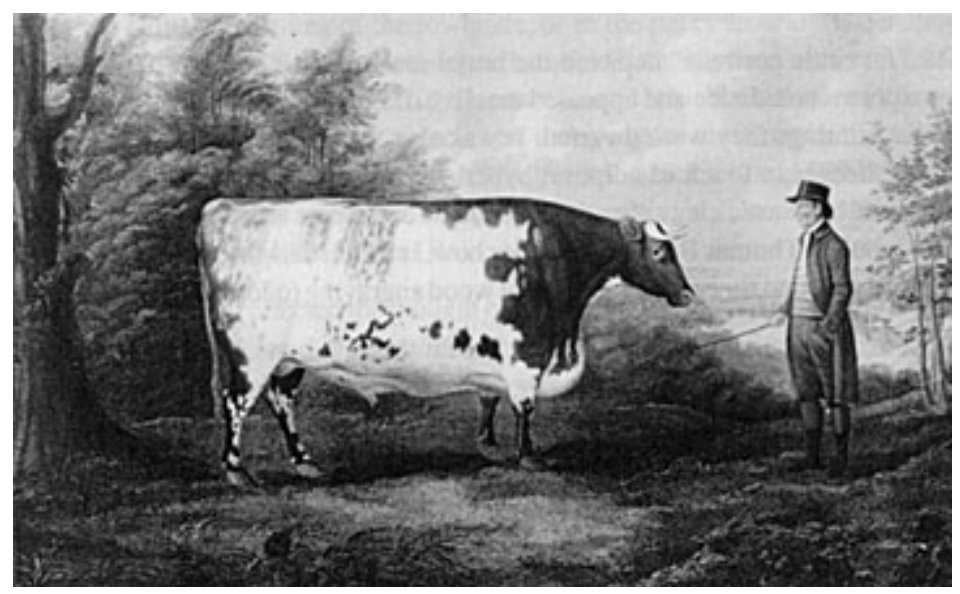

Fig. 1. The "Durham Ox," 1802. Source: (Quinn 1993)

Thus, the Durham cattle breed created by the Colling brothers, contemporaries and neighbors of Bakewell, became emblematic as the first cattle standard with fixed traits persisting 
from one generation to another across a whole group of animals, like a "static and codified object" (Loconto and Demortain 2017, 385). The painting of the Durham Ox (Fig. 1) famous for its shape, size and weight, is considered the first visual support for the standard that was to define the breed.

Since that period, over 1,000 cattle breeds have been officially created worldwide according to the breeding doctrine of Bakewell. It means that over 1,000 different standards have coexisted. Among them we count specialized milk breeds (Holstein, Brown Swiss, Ayrshire, Jersey, etc.), beef breeds (Hereford, Charolais, Angus, etc.) or several breeds for a double purpose (Simmental, Normande, etc.). The space of breeding has been organized by professional breeders applying theory, practices, and technologies such as mating choices and artificial insemination. Its geographical borders are traditionally delimited within national borders, as cattle breeding has been actively supported by States through public research and technology facilities, through funding and legal assistance, and through cooperative institutional arrangements.

Standardization through breeding drastically reduces the genetic variability of animals within breeds. At the same time, it proved to be a source of diversity via standardized diversification (Busch 2011), that is, through a multiplication of pure breeds. Every breed's standard is co-produced within a specific ecology that includes interactions between social, institutional, technological, and geo-climatic environments.

\section{Animal production as a space of standards in action}

Modern animal breeding is a human activity supporting and improving food production through a permanent process of genetic improvement of the animals' capacity to produce. It is a space of standards in action as the breed standards are continuously used and adapted. Farmers involved in cattle breeding are usually milk or meat producers. They look at different criteria related to their economic goals and chose one or a few breeds to constitute their herds. Such economically valuable traits [e.g., milk productivity, milk quality (butter fat and proteins), fertility, resistance to mastitis, meat quality] justify the farmer's choice of breed. Those qualitative, but measurable, traits are a significant part of breed standards. These are historically constituted through visually definable morphological traits (e.g., color, pattern, horn shape, animal's size), as is the case of the Durham Shorthorn breed. By investing in a particular pure breed, farmers engage to preserve the standard by applying strict mating rules between related animals. The methodology of breeding is progress oriented. It means that it fixes the standard and at the same time changes several traits in order to improve economic efficiency of the herd from one generation to the next.

Farmers involved within the same breed can form or join already existing breeders' associations that are collectively responsible for ensuring the correct application of the breed standard. Bull and cow shows and competitions are organized as moments and places of valuation to publicly confirm and promote the breed standard. We explain this through the example of the famous Durham standard as it expanded across Great Britain in the 19 century. In 1802 alone, the print of "The Durham Ox" (Fig. 1) was purchased by over 2,000 farmers in England and Scotland. This advertisement helped the further institutionalization of the breed at 
the national level through the creation and politicization of the national breed society (Russel 1986; Quinn 1993; Vissac 2002). That was the moment (the beginning of the 19" century) when cattle pedigree shows were massively introduced in England. Indeed, this proper use of the standard on farms is consistently reinforced within the farmer and breeder communities through the use of demonstrations, judging, and prizes during the shows. Often, the winners are used as stud animals to reproduce their winning traits for a fee. These mostly national associations thus encourage farmers to maintain the ideal standard breed.

This approach to encouraging the widespread adoption of a highly specified breed standard implicitly supposes that the environment where the animal is bred and productive is the same for different herds of the same breed. Thus, the most evident application of breed standards is still within a given country where specific breeding programs and associations are developed according to national political and economic goals. Indeed, at the beginning of industrial breeding, the environmental factor wasn't even taken into account because animals were usually considered as machines mechanically constituted for production (Fig. 2) and thus transferable anywhere. Once it was recognized that the physical environment impacted the productive capacities of cows, and thus their market value, attention shifted to the standardization of the broader production system. In the middle of the $20^{\text {th }}$ century, the American Holstein breed--the first specialized "milk machine"-was created as part of an intensive industrial farming system. In the Total Mixed Ration (TMR) system, stabled cows were fed standardized rations of concentrated feed. The pairing of standard breeds with artificialized production systems offered the farmer greater control over the productivity of the animals.

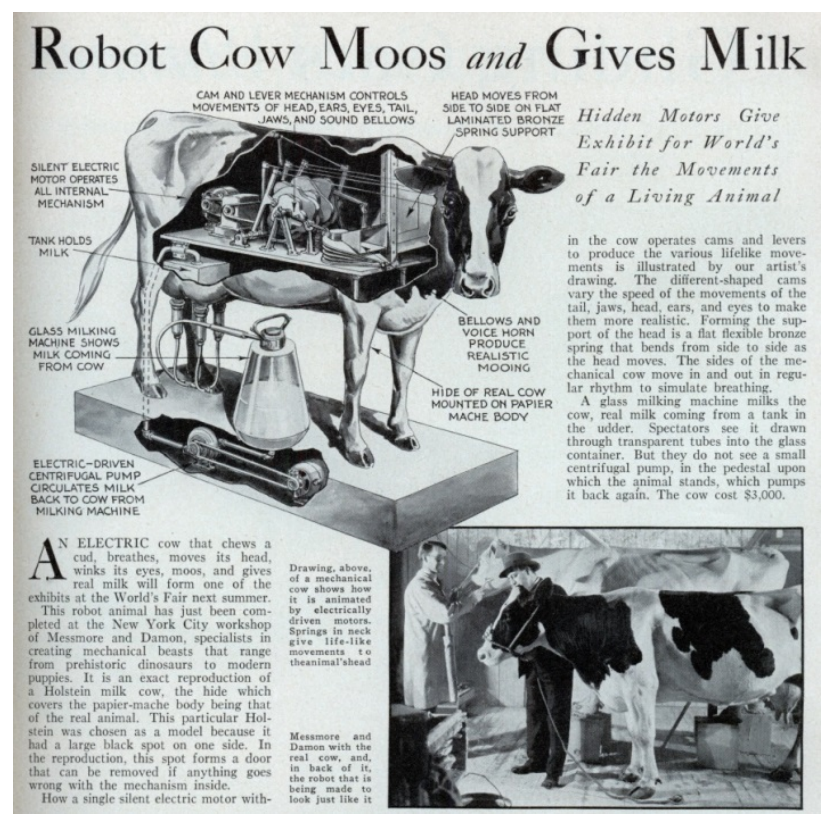

Fig. 2. The industrial dream: a robot cow conceived as a real cow. Source: http://blog.modernmechanix.com 
This environment, as the breeders refer to it, can be limited to the feeding system (pasture or TMR), to geo-climatic conditions (mountains or plains), to the technology of milking (robotic or manual), or to the country with its socio-economic priorities of selection and production, cultural traditions, farmers' beliefs and practices, consumers' needs, etc. In the industrial model, if one assumes that the adoption environment is the same, then the breed's standard remains formally unchanged. But diversity reemerges despite the standardization of the environment. For example, we are talking about living animals where there are genetic mutations or epigenetic mechanisms that are naturally occurring in a given herd. If those changes are undesired, the breeder can eliminate animals with such "anomalies" in order to preserve the standard of the pure breed. Or contrarily, if they are in line with the farmers' socio-economic production goals, the breeder can decide to keep them and even to enhance these new traits through the selection process. This would mean modifying the standard slightly or significantly, probably by crossing with other breeds and populations, until a new breed with different characteristics emerges. This does happen frequently, especially if we take into account a change in the environment of the breed standard. Thus, while the breeders use the term "environment" to explain this broader context, we refer to it as an "ecology," since the inclusion of the context within the standardization calculation is very much a social decision contingent on complex interactions among living beings within the space of action.

\section{The breeding market as a space of standards in circulation}

Circulation of cattle breeds as industrial standards can be illustrated with the same example of the Durham Shorthorn breed created in England. Arriving in France at the beginning of the 19 century, the Durham breed was not an immediate success. The French found the meat too fatty and its low milk productivity did not correspond to the French "lifestyle." Thus, while the standardized object did not meet expectations, the standardized selective breeding method was adopted by French breeders. They began to create new breeds based on the principles of Bakewell's genealogical doctrine. For example, the prized "La Normande" breed was the French adaptation of the Durham breed crossed with other cattle populations. Through the circulation of the standard into the French environment, the standard breed was defined inter alia by cultural traditions that differed from the English ones.

This practice of circulating standard breeds has developed significantly since the $19^{\text {th }}$ century and has moved from the circulation of cattle to the circulation of semen supported by the spread of artificial insemination practices and cryopreservation technology. The modern genetic resources market sustains the artificial insemination industry and the key actors are semen producers and distributors. To date, this space of standards in circulation is organized within the ontological paradigm of "pure breeds." This means that all genetic resources circulating in this space must be related to one of the roughly 800 documented breed standards that are left in the 
world. Crossbreeding (hybridization) is authorized, but the commercialization of crossbred germplasm is strictly prohibited.*

This circulation through a market is both national and international. At the national level, States regulate it through national breeding programs (or "schemes") that determine standardized procedures with precise criteria, means, and objectives for the selection process. These national programs are deeply science-based with public research institutions guiding the breeding process. In particular, the scientific knowledge about the crucial role of genetic diversity for sustainable animal selection helps to regulate mating between related animals. Indeed, genetic diversity is a highly sensitive issue for artificial selection. Choosing animals that are related for reproduction leads to a multiplication of homozygous alleles in chromosomes and ultimately to a loss of genetic variability, which is detrimental to a given population. This eventually leads to population disappearance. So, the circulation of the same breed standard through the genetic resources market can potentially endanger a breed standard if a necessary level of diversity is not preserved. A second important implication of the dominance of scientific knowledge in this space of circulation concerns the setting of breeding evaluation. Estimated Breeding Values (EBVs) are calculated with statistical genetics methods in order to qualify (define quality) and to give an economic value to marketed genetic products. The system of breeding evaluation, as all valuation processes, is locally situated (Dewey 2011) and in the case of cattle breeding depends on the national breeding schemes.

The internationalization of the genetic resources market can enhance diversity within the same breed standard if the change in the standard's ecology is taken into account and if the scale of evaluation accordingly changes. Not taking diversity and the standard's ecology into account can be detrimental for any given globalized breed. We illustrate this effect with the example of the Holstein-Friesian breed.

Two waves of internationalization marked the development of the Holstein-Friesian breed. The first took place in the $19^{\text {m }}$ century. Originating from the Netherlands, the Friesian breed, renowned for its robustness and balanced milk and meat productivity, expanded worldwide. This expansion mainly occurred through the trade of living animals with neighboring European countries and the overseas migration of Dutch and British farmers who travelled with their animals and their breeding know-how. During this period, the development of national stud industries and breeding programs, along with the relative difficulty of transporting animals, temporally limited international intra-breed circulations and interactions. Several diverging populations were thus developed in countries that welcomed the Black-andWhite Friesian cattle. These differences in genetic structure across differentiated strains were scientifically established and explained through a massive, experimental, comparative project launched by the Food and Agriculture Organization of the United Nations (FAO) in Poland in 1975. "All the tested strains are originated from Friesland, but it is extremely interesting to note how much they now differ owing to different selection goals and methods in different countries,"

${ }^{4}$ It will probably change soon with a pressing of private companies that are lobbying for the authorization to sell crossbred genetic resources like in plant industry. 
reads the conclusion of the article published by the scholars involved in the project (Jasiorowski et al. 1987, 62). Again, this illustrates how the circulation of the Friesian standard and its enactment in different locations created diversity. In this case, the diversity is found among different populations of the same breed adopted internationally. However, interactions in this space of circulation have become more complex with the intensification of international market exchanges.

The second wave of globalization (1960-70s) of the Black-and-White Friesian cattle occurred with one of the differentiated populations-the American Holstein-developed as the first specialized dairy breed in the world. A real "milk machine," it has become a symbol of the American cult of productivism. Its creation and international propagation were aided by artificial insemination (AI) technology. At the time, this breakthrough, along with the new cryopreservation technology, facilitated the spread of the genes with small doses of semen deposited into plastic tubes called straws. Freed of the difficulties surrounding the transport of live animals, the market-oriented North American Holstein breeding industry seized the opportunity to export its product abroad. Holstein, a gold standard of milk productivity, became the dominant breed on the international market. As of 2020, there were over 30 million HolsteinFriesian cows in the world (out of 1.4 billion cattle in total). The breed is present in approximately 130 countries (Fig. 3), 42 of which have developed their own breeding programs and are registered with the World Holstein-Friesian Federation. About 75 percent of the international trade in cattle genetic resources (mainly semen) come from the Holstein-Friesian breed.

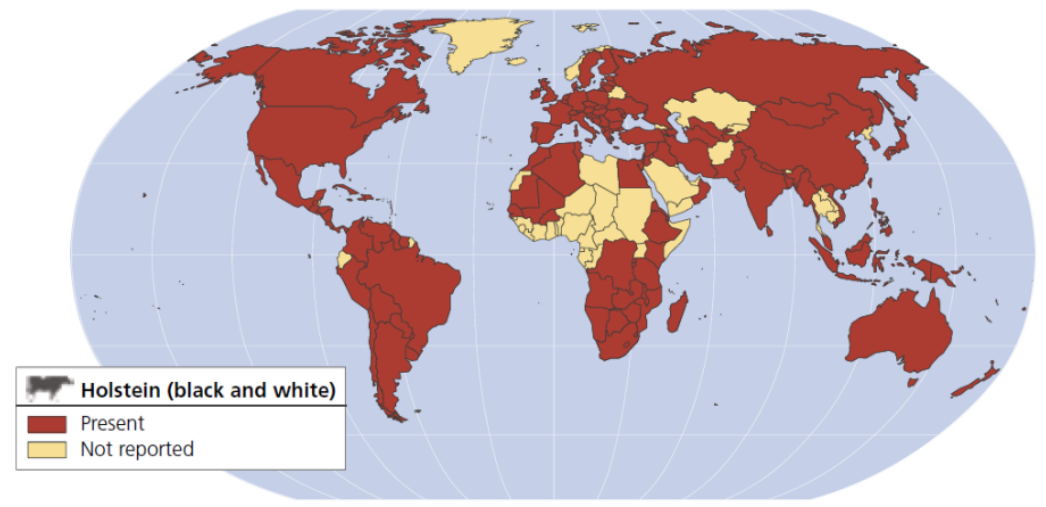

Fig. 3. Distribution of Holstein-Friesian cattle. Source: (FAO 2007, 11).

Within this breed, the loss of genetic variability was caused by the intensive use of a very small number of bulls renowned for their "productivity" genes, ${ }^{,}$mainly from USA. This so-called star-system pushed standardization to its extreme and accelerated the loss of genetic variability within the worldwide Holstein population. The tension between the market globalization of the

s Strictly speaking, no "productivity" gene exists. Productivity is a measured characteristic combining different polygenic traits (i.e. determined by a large number of genes). 
breed and its local evaluation became crucial to resolve. The differentiation of different Holstein populations according to their ecologies became important for the survival of the breed. Scientists, breeders, and traders began to question how they were to estimate breeding values within different national contexts and if the global marketplace had to account for these differences or to ignore them. Traders (mostly North-American companies) wanted to assume the same breed standard (implicitly the American one) everywhere. The scientists' position was to maintain the diversity of national breeding standards, which they justified according to the objectivity of evaluation and the preservation of genetic diversity within the globalized breed. They engaged each other to find a solution that reconciled the need for standardization that enabled the circulation of products in the global marketplace with the need to preserve diversity that was crucial for the sustainability of selective cattle breeding.

\section{Commensuration of Breeding Values as a Space of Standards in Interaction}

The above questions test the boundaries of the space of circulation and we thus suggest considering a fourth space of standardization: standards in interaction. In this space, different contextualized standards can coexist and interact. We demonstrate how this works by examining the case of Interbull (International Bull Evaluation Service). Interbull started as a European initiative in response to the worldwide expansion of the hegemonic American breeding standard. International actors created it in order to apply the principle of "coexistence" in the organization of the international cattle breeding market. This principle relies upon the political concept of subsidiarity in order to preserve diversity. As previous authors (Jasanoff 2013; Doganova and Laurent 2016) have shown, considerable and powerful regulatory apparatus are needed to apply this principle. We suggest that these apparatus operate according to a logic of commensuration (Espeland and Stevens 1998; 2008; Desrosières 2014; Busch 2013). Defined by Espeland and Stevens $(1998,2008)$ as one of numerous forms of standardization, the commensuration process establishes the equivalence (Desrosières 2014) between objects or phenomena through common metrics in order to make them comparable and to open up a space for them to interact without necessarily needing to be completely homogenized. As a deeply socio-technical notion, the "commensurability of standards is important only when people and things come in contact with one another" (Busch 2013,38). Put differently, a new space of standards in interaction can emerge that offers the possibility for people, things, and standards to coexist and interact while maintaining their diversity. Interbull can thus be seen as an overt attempt to develop a sociotechnical device for commensuration with the purpose of organizing the circulation of and interaction between coexisting national standards for cattle breeding. We explain how this happened in the following sections.

\section{A political issue of breeding values}

In the 1970s, during the era of mass "holsteinization" (genetic absorption of Friesian populations by the American Holstein strain), the comparability of breeding values across imported and local 
cattle became an important issue. As one of the interviewed actors mentioned, "American Holsteins arrived with high EBVs of $+2,000,+2,300$, which impressed farmers. But farmers were completely lost because no one could compare these numbers." They expressed values given to animals of the same breed but embedded within different environments. Put differently, they represented different ecologies of the same standard. It would thus seem that while numerical/quantified values could be considered comparable, they were definitely not commensurable.

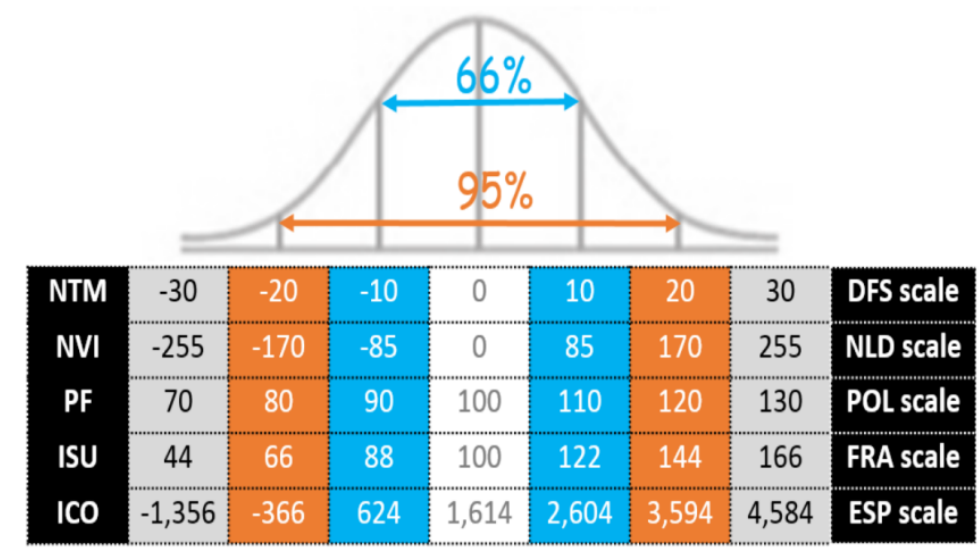

Fig. 4. "How to understand total merit indices": Visual representation of five European evaluation scales. Source: Eurogenomics

National borders determine the ecology of the breed standard through the national organization of breeding programs. Implicitly, this supposes differences in the expression of genetic values between countries. For example, the ISU (Index de Synthèse UPRA) in France, the EBI (Economic Breeding Index) in Ireland, the NTM (Nordic Total Merit) in Scandinavian countries, the PF (Production and Functionality) in Poland, the NZMI (New Zealand Merit Index) in New Zealand, and the TPI breeding evaluation standards. They include different economic priorities for selection, which lead to different choices of traits to measure. In France, for example, traditional cheese production requires high protein content in milk. This trait therefore has to be measured and needs to be highly accurate. In the United States, farmers value a very high milk yield stimulated by a rich diet. Meanwhile, in New Zealand the priority is neither a very high milk yield nor high protein content, but rather cows' capacity to produce in variable feeding conditions with all-year grazing. Thus the same trait, "milk production," does not reflect the same characteristics from one country to another. Farmers sometimes use different metrics to measure cows' performances.

For example, is milk production expressed in kilograms, pounds, or liters? Statistical models used to calculate EBVs can also vary across countries, from one national evaluation center to another. Unsurprisingly, all this makes comparing the results of such measurement rather

- Compared to values of the order of $+100,+150$ in France, for example.

- Interview with one of the pioneers of Interbull (31/05/2016). 
difficult. Figure 4 gives an example of some of the differences between the five European evaluation scales. In particular, we can see that the mean and the variability of the index have different numerical expressions from one country to another.

The most renowned evaluation standard (also the most contested at international level) is the famous American TPI ${ }^{\mathrm{w}}$. The name was even trademarked to highlight its market orientation and legal protection. With the second wave of globalization of the Holstein breed, TPI became a bone of contention between market actors and the scientific community. Although it dominates the market and is accepted by breeders and farmers worldwide, many geneticists criticize TPI ${ }^{\mathrm{m}}$ for hindering genetic diversity. It focuses on milk productivity and type traits, and favors the American standard of tall and angular cows suitable for "beauty contests." It thus gives less importance to other traits that are economically significant for many farmers in other countries, such as fat and protein content, udder health, fertility, etc. While the same American standard of cow is promoted everywhere by North-American semen sellers, many geneticists consider this free market competition detrimental to sustainable animal breeding. In order to counter this negative effect, in the 1970s, European scientists brought the issue of the incomparability of breeding values between North American imported bulls and local ones to the political arena.

\section{Accounting for the "genotype by environment interaction" effect as a solution for the commensurability of breeding values}

The issue for geneticists was to keep the diversity of breeding evaluation standards in order to counter the American TPI dominance and to preserve some genetic diversity within the globalized Holstein-Friesian breed. In the middle of 1970's, expert groups were set up within international non-governmental organization like FAO, IDF (International Dairy Federation) and EAAP (European Federation of Animal Science) in order to find a technical solution to make different breeding values comparable. Over a period of nearly twenty years, experts studied differences between national breeding systems. This task was made extremely difficult due to the classification of different kinds of information as trade secrets. First, they tested the method of conversion between national breeding values using a principle similar to that of currency convertibility that was recognized as unreliable and too complicated to manage on the global level. Geneticists ended up identifying a statistical solution for breeding evaluation. The method was based on the statistical identification of a genotype by environment interaction $\left(G^{*} E\right)$ effect that could be calculated at the genetic level of live organisms (plants or animals economically valuable by humans). This calculation means that the genetic value of a given organism has a complex relationship with its environment. Highly heritable, this complexity can, and must, be taken into account in the process of breeding evaluation (James 1961). Demonstrated statistically, this scientifically objective knowledge helped experts find a model and to apply it for computing internationally commensurable breeding values.

In the early 1990s, a model called MACE (Multiple-trait Across Country Evaluation) was developed (Schaeffer et al. 1993). Accounting for the genotype by environment interaction effect where the "environment" was defined as "country," it could "translate" the breeding values of 
animals calculated in Country A into the values these animals would have in Country B. The ranking of marketed bulls could therefore change from one country to the next (Fig. 5). The concept of commensuration became a reality with the possibility of objectively comparing the "quality" of genetic products across different countries.

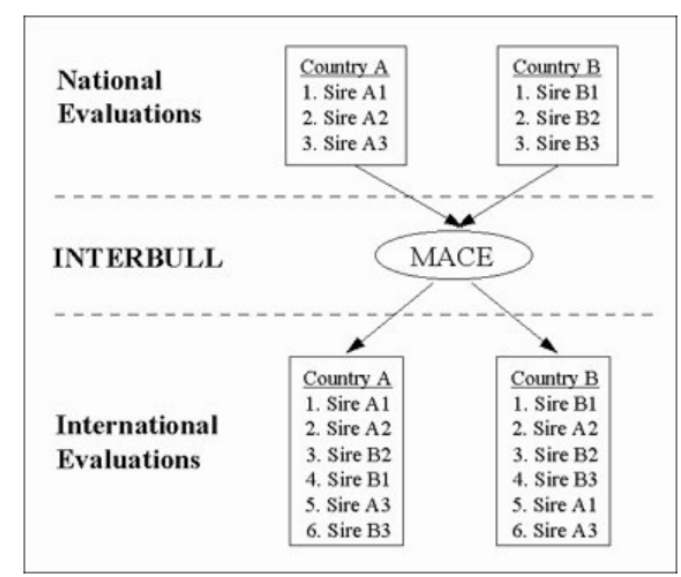

Fig. 5. Changes in bull rankings in international evaluations for Countries A and B. Source: Interbull

The MACE model met the main technical objectives set out by the international professional community: (i) it allowed for information to be processed on a multilateral level; (ii) it did not require countries to share strategic information that revealed trade secrets to their international competitors; and (iii) it accounted for genotype by environment interaction effects as an "objective" dimension that differentiated marketed animals of the same breed according to their genetic potential in specific national contexts. Despite its technical validation by peers, getting countries to accept the tool was not as simple as the experts first thought. This commensuration work involved multiple layers of negotiation and compromise in order to introduce it into more or less stabilized networks of national cattle breeding systems and make them interact in line with the model.

\section{Interbull as a techno-political space of commensuration}

Despite all technical the benefits of the MACE model, its acceptance by market actors was not straightforward. Differentiating the breed standard by accounting for the different ecologies in which it can be applicable was a highly contested matter. The semen industry advocated the need to simplify the process by accepting the assumption of an identical environment everywhere and therefore the same ranking for all bulls across all countries. According to the scientific position, accepting the market logic could lead to the loss of diversity and thus to the end of cattle breeding as it was then known (i.e. the pure breed paradigm). Over the course of numerous rounds of technical and political negotiation, Interbull as a service of international breeding 
evaluation was launched with the MACE model. The Interbull Computing Center was established in 1994 in the University of Agriculture (SLU) in Sweden. After an official competition between computing centers in different countries, Sweden was chosen because of its relatively "neutral" position on the global market of Holstein genetic resources. That criterion was judged important to maintain the objectivity of Interbull's international commensuration work.

The first international evaluations were computed for the first nine member countries, for milk production traits only. As of 2020, 34 countries (Fig. 6) benefit from these evaluations for six globalized dairy breeds, Holstein, Brown Swiss, Airshire, Jersey, Guernsey and Simmental, and an important variety of traits. This means that since 1994, 25 more countries created or confirmed their own standards of different globalized breeds incorporated into diverse national ecologies.

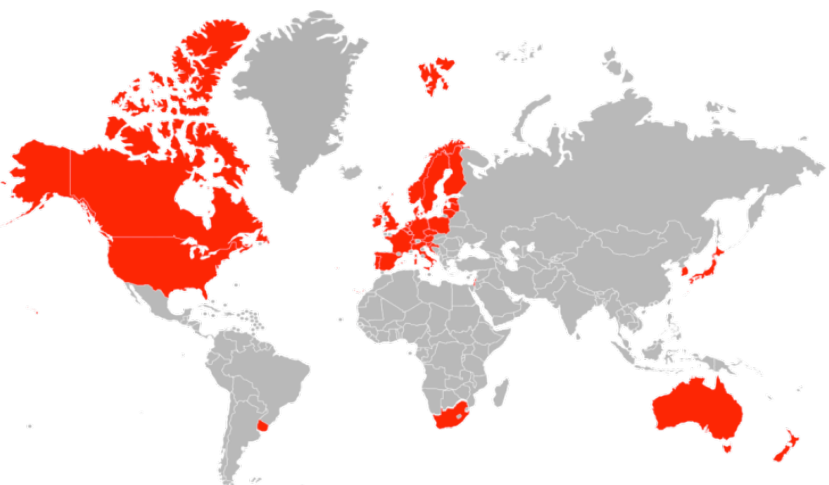

Fig. 6. Countries members of the Interbull's space of commensuration. Source: Interbull

To make this space of interaction work on a daily basis, a set of administrative procedures establish Interbull as a service organization. The Interbull Code of Practices (1994) was developed to help users of the commensuration service--National Centers for Genetic Evaluations-to harmonize the delivery of their data. Using Interbull services also involved compliance with technical requirements (certifications, tests), as well as administrative and legal formalities (service contracts, payment of fees). Thus, users became members of an organization. The Center gradually recruited permanent staff to ensure its day-to-day operational work as a service provider. Backed by the University's research department and through close interaction with the Interbull Technical Committee and Scientific Advisory Committee (created several years later), the Center had all the technical and scientific skills to become the hub of international genetic evaluations. Interbull thus became a powerful Latourian "center of calculation" (Latour 2006). MACE was and still is calculated on a routine basis. The results are sent to member countries that are responsible for publishing them. This is a requirement set out in the Interbull 
Code of Practices (1994): member countries must publish and make official the evaluations produced by Interbull.

Routine evaluations are run three times a year (April, August, and December) by the Interbull Computing Center. Choosing the number and dates of these evaluations may seem like a rather "mundane" problem, but it is precisely the one that interviewees reported to be the most complicated to solve in the techno-political negotiation process. Evaluation periods had to be scheduled at the national level based on the many parameters [evaluation costs, geo-climatic conditions, animals' biological cycles (though shaped by technology), farmers' practices and traditions, etc.]. The dates of publication of bulls' genetic values and rankings are an important criterion for market efficiency, as it determines which bulls are to be sold. Deciding on evaluation dates was therefore unquestionably a key part of the international commensuration process.

At present, geneticists (five staff at the time of inquiry) assisted by IT specialists (three staff at the time of inquiry) at the Interbull Computing Center run more or less standardized and automated programs ("scripts") to calculate international EBVs. All the data received from the different countries are analyzed together, in line with MACE technical requirements. This involves calibrating the input data. But as the commensuration process strives to preserve the initial diversity of national evaluation scales rather than provide a single international ranking of bulls, it entails a twofold "translation" process. Upstream, Interbull Center correspondents within the National Genetic Evaluation Centers collect genetic indices from the people in charge of national genetic evaluations. They process this data to meet the formats and codes established by Interbull. Downstream, once the international indices have been calculated, Interbull geneticists translate them back into each country's scale. They then distribute them to their national points of contact in charge of publishing and disseminating the rankings of international indices to cattle breeding professionals. Both processes are normalized and follow highly precise technical protocols in order to avoid heterogeneity in the data formats.

So, in practical terms, I get the information, the files and I format them. Formatting means recoding them as Interbull wishes, with file formats as defined by Interbull. (A correspondent of the Interbull Center in France, interview from 15/12/2016)

What we are asked to send is very clear, very precise, if it is not in the right format, you cannot upload your data, [...] if you are missing a comma, your file is rejected. (A former correspondent of the Interbull Center in France, interview from 10/11/2016)

Commensuration, as a real standard setting process, is requiring a huge technical and administrative apparatus. The issue of reliability and objectivity is crucial for the acceptability by an international community of animal breeding professionals. As the reliability of the commensurate values hinged on the quality of the input data provided by countries, national evaluation standards had to be calibrated to become potentially commensurable.

It's wonderful to have methods to combine national evaluations at the international level. But if national evaluations are not reliable, that impacts international comparisons and rankings. If you 
use wrong ingredients to cook, you risk to be surprised by the result. (A member of Interbull Steering Committee, interview from 12/05/2016)

A validation test was thus developed to ensure that national evaluations did not introduce any bias into shared international evaluations. It was decided that each country's evaluation center would have to run these tests before being allowed to participate in international evaluations.

The space of commensuration is not, however, limited to the technical computing of international values. It is a space where knowledge is circulating and validated by a hybrid community of cattle breeding professionals. Every year since the 1980s Interbull organizes well attended congresses, conferences, and workshops. Cattle breeding professionals debate technical development and improvement of methods of evaluation. They also meet to discuss political issues linked to situations where national practices are challenged by globalization. Thus, the story of Interbull is about the construction of a space of equivalence (Desrosières 2014), through commensuration (Espeland and Stevens 1998), of national breeding standards coming together and interacting on the global market (Busch 2011). Our analysis of the Interbull case came to a close at the peak of its international success as a space of commensuration. In 2009, the new technology of genomic evaluation brought new issues and a new distribution of roles between stakeholders (Chavinskaia, Ducrocq and Joly 2017; Chavinskaia 2020). However, the value of diversity remains paramount to its activity, as standardization efforts seek to maintain the diversity of national ecologies and standards by facilitating their interaction.

\section{Discussion}

This case of cattle breeding standards offers an opportunity to clarify the concept of standardization as spaces of diversity. We recognize that all four spaces are dynamic and interactive, but we attempt here to present them through simple graphic models in order to highlight the diversity found in and between these spaces.

The space of "standards in the making" (Fig. 7), provides a space to set up different standards for different purposes and thus within different ecologies. The diversity here emerges from the differentiation of standards as they are created in specific, and diverse, ecologies. This space corresponds to the example explained above about the activities surrounding the creation of breeds since the 18th century.

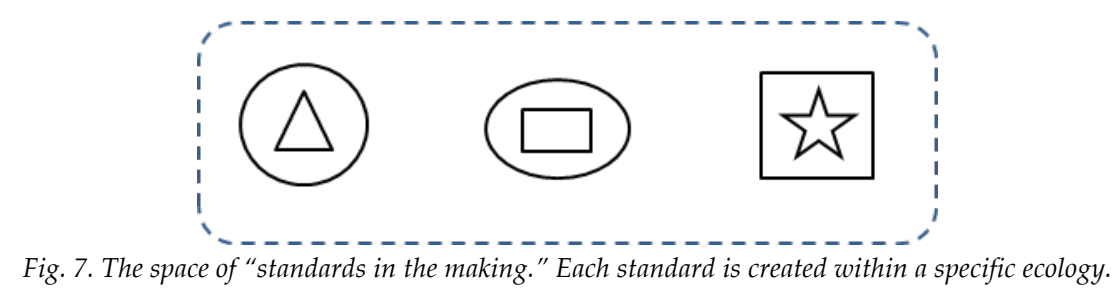


The second space-“standards in action" (Fig. 8)—operates as a space where a given standard is meant to be applied by users. For this application to work, the ecology is supposed to be similar or completely ignored by the standard's users. Thus, the standard and its ecology must be displaced into new areas of application. This is the industrial model where breeders try to standardize the ecologies in order to apply the standards. What we found, of course, is that diversity emerges through different interpretations and appropriations of rules by standards' users. However, these "slippages" (Lampland and Star 2009) are considered by users and standards-setters as insignificant. The standard itself is not questioned. The creation of commercial herds by farmers investing in one or few standard cattle breeds illustrates this diversity within the space of standards in action.

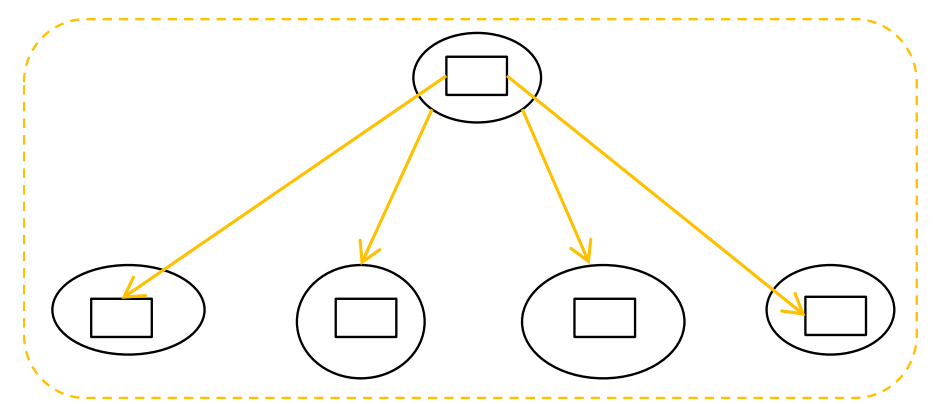

Fig. 8. The space of "standards in action." The application of the same standard is determined by the assumption that the ecology stays similar.

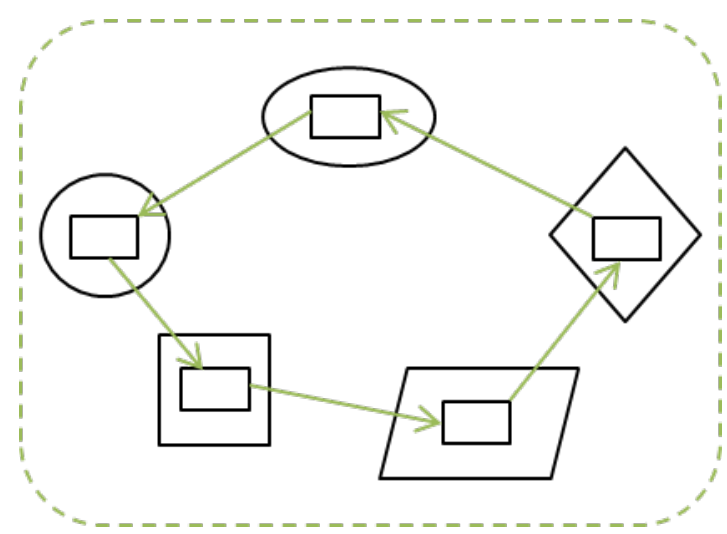

Fig. 9. The space of "standards in circulation." The same standard can circulate between different ecologies questionning thus the integrity of the standard.

The third space of "standards in circulation" (Fig. 9) lets standards circulate between different ecologies and questions their entrenchment within the original ecologies that shaped the creation of the original standard. The standard thus can be adapted to a new ecology until it changes completely and becomes a new standard. The space of standards in circulation interacts 
in this case within the space of standards in the making. We illustrated this space with the example of the international cattle breeding market where genetic resources of a given breed can be sold and bought by farmers and breeders in different countries. The early international circulation of breeds often resulted in major modifications to the breed standards that led to the creation of new ones (e.g., the English Durham Shorthorn that was used in France to create La Normande breed). Here diversity emerges both within the standards and in their ecologies.

However, the worldwide expansion of the Friesian Black-and-White cattle tests the contours of this space. The breed admittedly changed in different countries that welcomed its populations. However, the globalization of the genetic resources market facilitated circulations between those Black-and-White populations that were still considered to be the same breed, but not the same standard because of its ecology induced modifications. Thus, a fourth space of "standards in interaction" (Fig. 10) can be differentiated from the space of circulation.

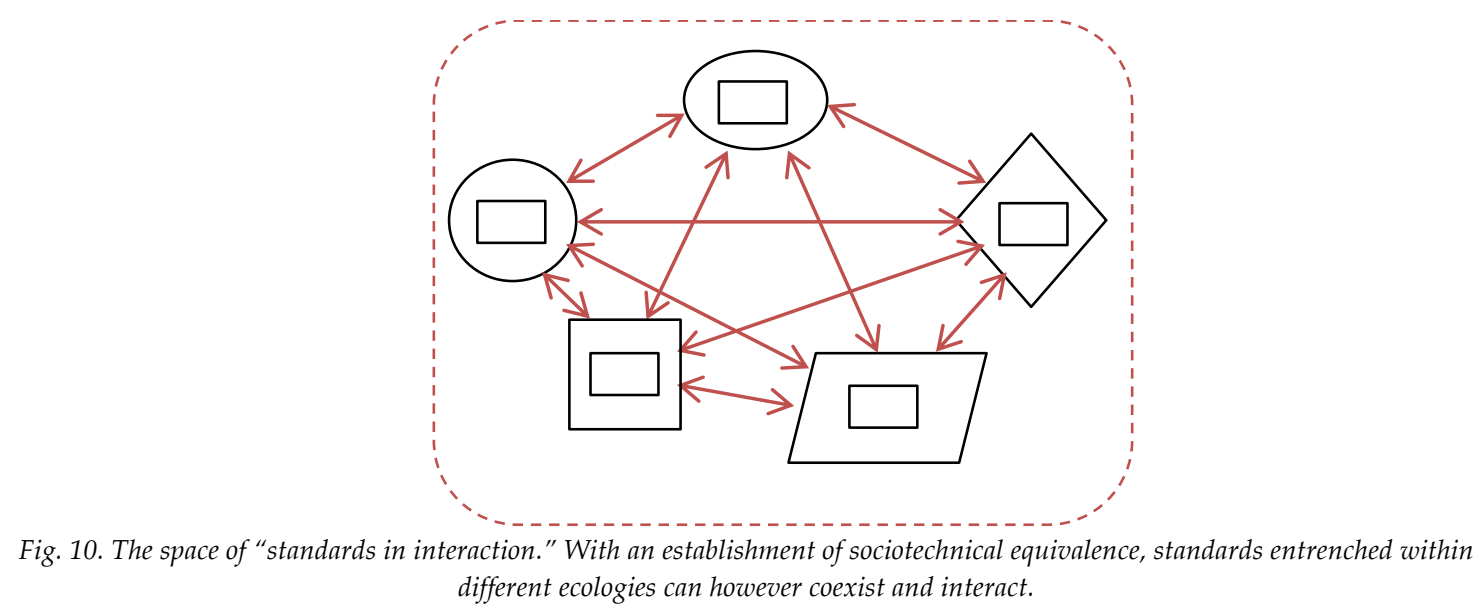

We observed that the notion of a pure breed was questioned by the internationalization of the genetic resources market. Thus, when the notion of a standard is questioned by the notion of ecology, the problem of interaction between standards entrenched within different ecologies must be resolved. Usually this tension is resolved by creating a space of equivalence; in our case of cattle breeding this is a space of commensuration of breeding values. Such a space is needed when standardized entities meet in the same place and must interact with each other without harmonizing, but by maintaining their unique diversities. This is what happened in the globalized cattle breeding market where the establishment of equivalencies between breeding values guarantees the quality of the circulating products. Such "meta-standardization" is usually observed in spaces involving multiple actors (e.g., at international level), where we find efforts to harmonize or calibrate different standards in circulation in order to keep the diversity under control (Loconto and Fouilleux 2014). But rather than focus on a hierarchical vision of commensuration as a meta-standard, or simply a new space of standards in the making, we argue that commensuration takes its place in interaction with the three other spaces of standardization. 
Commensuration aims precisely to preserve diversity through coexistence of and interaction between different standards encouraging their proliferation. Figure 11 offers a graphic vision of how this interaction among spaces could take form. Based on the dynamics explained through the experience of cattle breeding standards, we find that the passage of a standard from one space to another depends largely on the degree of entrenchment of a given standard within its ecology (cf. Star and Ruhleder 1996).

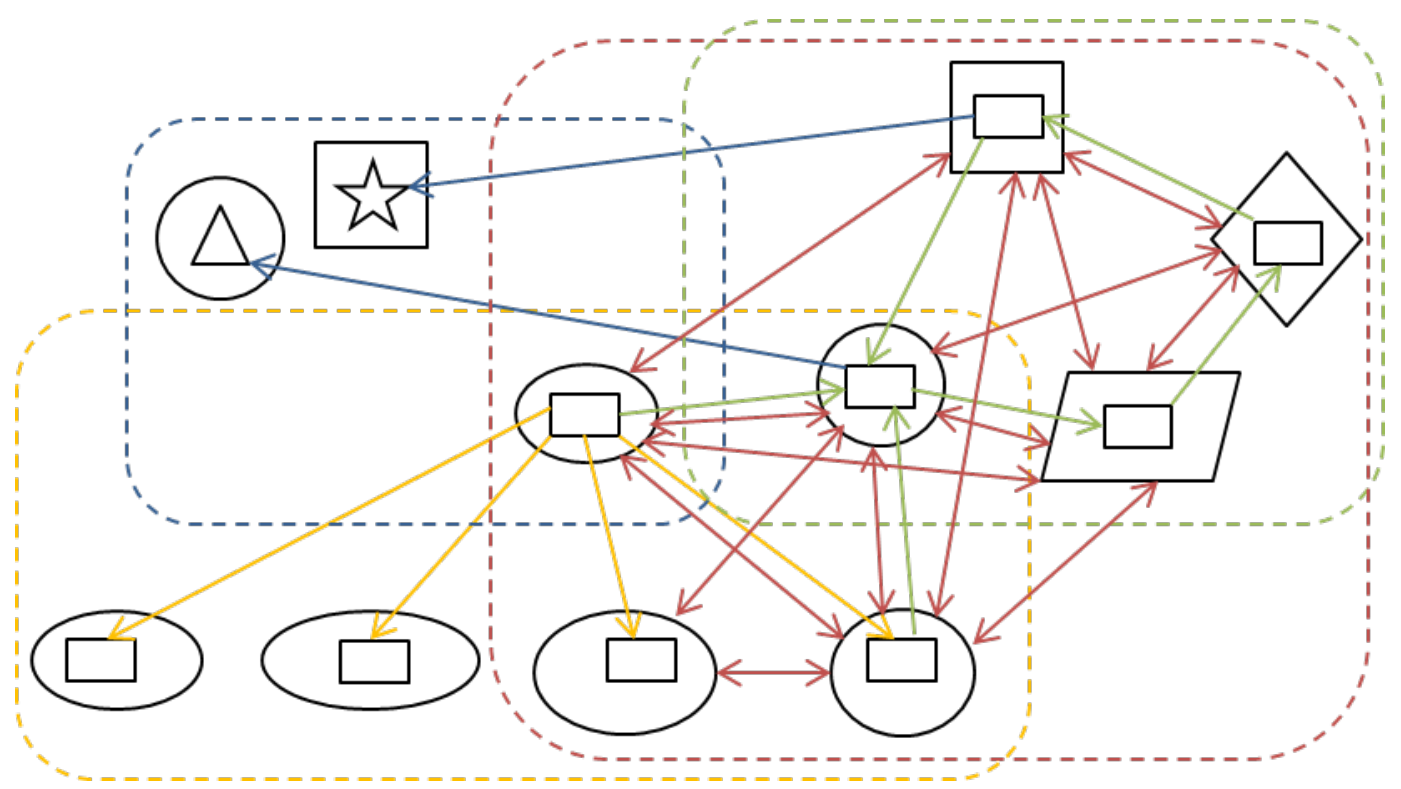

Fig.11. The four spaces ("standards in the making" in blue, "standards in action" in yellow, "standards in circulation" in green, and "standards in interaction" in red) in their dynamic and interactive representation.

\section{Conclusion}

By taking a socio-technical approach to studying cattle breeding standards, we usefully advance Loconto and Demortain's (2017) conceptual framework of three spaces of standardization through which diversity can reemerge. We use the notion of commensuration to introduce a fourth space of "standards in interaction." Indeed, a process of socio-technical equivalence (Desrosières 2014) must be engaged to allow different standards coexist, interact, and even proliferate efficiently. Thus standards, when they interact, necessarily bring with them their institutional ecologies (Star and Griesemer 1989). This characterization of standards helps us to deal technically and politically with the diversity that we observe when standards interact across different ecologies.

Analyzing cattle breeding as an industry where standardization concerns live organisms offers unique insights into the diversities of a standard entrenched in its ecologies. Indeed, the 
live organisms are inherently and biologically part of their ecologies. This point of view problematizes industrial standardization of animals because the question of diversity becomes crucial for the sustainability of the artificially created animal populations involved in industrial production systems. We thus identified how a necessary degree of diversity is maintained through different spaces of standardization. Although our insights come from a particular type of standard for live organisms, we argue that this "space of interaction" offers new avenues for research within the sociology of standards.

\section{Acknowledgements}

We thank the INRAE Metaprogramme SelGen for funding this research, Vincent Ducrocq for his attentive review of technical details and all the actors who accepted to be interviewed or provided information. We also thank the anonymous reviewers for their constructive comments.

\section{Author Biography}

Lidia Chavinskaia is a PhD candidate in sociology the Interdisciplinary Laboratory for Science, Innovation and Society (LISIS). After a long professional experience within the international relations department of the French National Institute for Research on Agriculture, Food and Environment INRAE, she is carrying out a research work on the globalization of agricultural technologies.

\section{Author Biography}

Allison Loconto, PhD in sociology, is Deputy Director of the Interdisciplinary Laboratory for Science, Innovation and Society (LISIS) and Senior Researcher at the French National Institute for Research on Agriculture, Food and Environment (INRAE). Her research focuses on governance by standards, innovations in certification systems, responsible innovation, and the governance of transitions toward sustainable agriculture.

\section{References}

Akrich, M., M. Callon and B. Latour. 2006. Sociologie de la traduction: Textes fondateurs. Paris: Presses des Mines.

Becker, H. S. 2011. Art Worlds. Berkley: University of California Press.

Bourdieu, P. and L. Waquant.1992. Invitation to a Reflexive Sociology. Chicago: University of Chicago Press.

Bowker, G. C. and S. L. Star. 2000. Sorting Things Out. Classification and Its Consequences. Cambridge: The MIT Press. 
Brunsson, N., A. Rasche and D. Seidl. 2012. "The Dynamics of Standardization: Three Perspectives on Standards in Organization Studies." Organization Studies 33(5-6), 613-632.

Busch, L. 2011. Standards. Recipes for Reality. Cambridge: The MIT press.

Callon, M. 1986. "Some elements of a sociology of translation: domestication of the scallops and the fishermen of St Brieuc Bay." In Power, action and belief: a new sociology of knowledge? edited by J. Law, 196-223. London, Routledge.

Chavinskaia, L., V. Ducrocq and P.-B. Joly. 2017. "Interbull: Constructing International Commensurability for Dairy Cattle Selection." Interbull Bulletin, 51. https:/ / journal.interbull.org/index.php/ib/article/view/1428/1493

Chavinskaia, L. 2020. "La science fait de la résistance. » Revue d'anthropologie des connaissances" 141. Accessed 14 March 2020. http:/ / journals.openedition.org/rac/4262

Desrosières, A. 2014. Prouver et gouverner. Une analyse politique des statistiques publiques. Paris: La Découverte.

Dewey, J. 2011. La formation des valeurs. Paris : La Découverte.

Doganova, L. and B. Laurent. 2016. "Keeping things different: coexistence within European markets for cleantech and biofuels." Journal of Cultural Economy, 9 (2), 141-156.

Espeland, W. N. and M. L. Stevens. 1998. "Commensuration as a Social Process," Annual Review of Sociology, 24: 313-343.

Espeland, W. N. and M. L. Stevens. 2008. "A Sociology of Quantification." European Journal of Sociology, 49: 401-436.

FAO. 2007. "The State of the World's Animal Genetic Resources for Food and Agriculture." Commission on genetic resources for food and agriculture, FAO, Rome 2007.

Fligstein, N. and D. McAdam. 2015. The Theory of Fields. Oxford University Press.

Fouilleux, E. 2000. “Entre production et institutionnalisation des idées. La réforme de la politique agricole commune." Revue française de science politique, 50 (2):277-305.

Higgins V. and W. Larner. 2010. "From Standardization to Standardizing Work." In Calculating the Social, edited by V. Higgins and W. Larner, 205-219. London: Palgrave Macmillan.

Interbull Code of Practice. 1994. https://interbull.org/ib/codeofpractice Accessed 13 February 2017.

James, J. W. 1961. “Selection in two environments." Heredity, 16: 145-152.

Jasanoff, S. 2004. States of knowledge. The co-production of science and social order. London and NewYork: Routeledge.

Jasanoff, S. 2013 "Epistemic subsidiarity - coexistence, cosmopolitanism, constitutionalism." European Journal of Risk Regulation, 4 (2):133-141.

Jasiorowski, H. A., M. Stolzman, and Z. Reklewski. 1987. "International FAO Black and White Cattle Strain Comparison (1974-1984)." World Animal Revue, 62: 2-15.

Joly, P.-B. and C. Marris. 2003. "La trajectoire d'un problème public : une approche comparée du cas des OGM en France et aux Etats-Unis." In Risques collectifs et situations de crise. Apports de la recherche en sciences humaines et sociales edited by C. Gilbert, 41-63. Paris: L'Harmattan.

Lampland, M. and S. L. Star. 2009. Standards and their stories: how quantifying, classifying, and formalizing practices shape everyday life. Ithaca: Cornell University Press. 
Latour, B. 2006. “Les 'Vues' de l'esprit. Une introduction à l'anthropologie des sciences et des techniques." In Sociologie de la traduction. Textes fondateurs., edited by M. Akrich, M. Callon, and B. Latour, 33-69. Paris : Les Presses de Mines.

Loconto, A. M. 2017. "Models of assurance: Diversity and standardization of modes of intermediation." Annals of the American Academy of Political and Social Science, 670 (1): 112132.

Loconto, A. M. and D. Demortain. 2017. "Standardization as Spaces of Diversity." Engaging Science, Technology, and Society 3: 382-392. https:// doi.org/10.17351/ests2017.155

Loconto, A. M. and E. Fouilleux. 2014. "Politics of Private Regulation: ISEAL and the shaping of transnational sustainability governance." Regulation \& Governance 8 (2):166-185. https:// doi.org/10.1111/rego.12028

Powell. W., D. White, K. Koput, and J. Owen-Smith. 2005. "Network Dynamics and Field Evolution: The Growth of Interorganizational Collaboration in the Life Sciences." American Journal of Sociology 110:1132-1205.

Quinn, M. S. 1993. "Corpulent Cattle and Milk Machines: Nature, Art and the Ideal Type." Society and Animals 1 (2): 145-157.

Rip A. and P.-B. Joly. 2012. "Emerging Spaces and Governance." A position paper for EU-SPRI.

Russell, N. 1986. Like engend'ring like. Heredity and animal breeding in early modern England. Cambridge University Press.

Schaeffer, L. R., A. Robinson, J. Chesnais, H. Wilmink, G. Wiggans, P. Rozzi, H. DeBoer, and M. Hunt. 1993. "Multi-trait, across country evaluation of dairy sires." Interbull Bulletin, No. 8.

Selmi, A. and P.-B. Joly. 2014. "Les régimes de production des connaissances de la sélection animale. Ontologies, mesures, formes de regulation." Sociologie du Travail, 56: 225-244.

Star S. L. and J. R. Griesemer. 1989. "Institutional Ecology, 'Translations' and Boundary Objects: Amateurs and Professionals in Berkeley's Museum of Vertebrate Zoology, 1907-39." Social Studies of Science, 19 (3), 387-420.

Star, S. L., and K. Ruhleder. 1996. "Steps Toward an Ecology of Infrastructure: Design and Access for Large Information Spaces." Information Systems Research, 7(1): 111-134.

Timmermans, S. and S. Epstein. 2010. "A World of Standards but not a Standard World: Toward a Sociology of Standards and Standardization." Annual Review of Sociology 36 (1): 69-89. https: / / doi.org/10.1146/annurev.soc.012809.102629

Vissac, B. 2002. Les vaches de la République. Saisons et raisons d'un chercheur citoyen. Paris. Inra Editions.

WHFF (World Holstein-Friesian Federation). 2017. "2017 Annual statistic report-World." http:/ / www.whff.info/documentation/statistics.php\#go1 